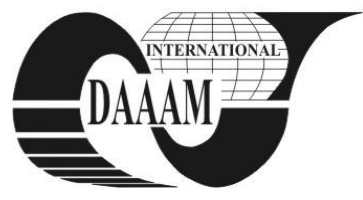

Annals of DAAAM for 2011 \& Proceedings of the 22nd International DAAAM Symposium, Volume 22, No. 1, ISSN 1726-9679 ISBN 978-3-901509-83-4, Editor B. Katalinic, Published by DAAAM International, Vienna, Austria, EU, 2011 Make Harmony between Technology and Nature, and Your Mind will Fly Free as a Bird Annals \& Proceedings of DAAAM International 2011

\title{
MODEL FOR ACCOUNTING INFORMATION VALUATION, USING MULTIPLE LINEAR REGRESSION
}

\author{
RADNEANTU, N[icoleta]; STAN, E[lena] R[oxana] \& GABROVEANU, E[milia]
}

\begin{abstract}
The growing importance of intangible assets can be seen while the emergence of knowledge-based economy makes its presence felt. This paper is trying to highlight the importance of intangible assets which are not recorded in traditional financial statements for generating added value. The connection among ROA (Return on Assets), balance sheet indicators and the given grades to some intangible elements is analyzed for the knowledge-based organizations managers and other organizations managers of the Top 100, according to market capitalization, listed on Bucharest Stock Exchange (BSE). The analyze is made using multiple linear regression.

Key words: intangible assets, ROA, multiple regression, independent variables, dependent variables
\end{abstract}

\section{INTRODUCTION}

The major problem of intangible assets is based on the impossibility of being assessed. In time many valuation models - e.g. Direct Intellectual Capital Methods, Market Capitalization Methods, Return on Assets Methods, Scorecard Methods (Luthy, 1998) -, have been issued, but unfortunately, most of them can not generate comparability of data obtained after evaluation of different organizations. The main arguments regarding the need for a new model for assessing intangible assets may be the difficulty and high costs involved in measuring them, the uncertainty of results and the impossibility of recording social phenomena with scientific precision. Since now, there is no reference of the existence of a model using intangible assets not recognized in traditional financial statements in Romania.

\section{CREATING A MODEL FOR PROFITABILITY MEASUREMENT USING MULTIPLE REGRESSION}

In order to achieve an econometric model to determine companies profitability by using intangible assets not recorded in traditional financial statements we introduced in SSPS the responses of knowledge-based organizations managers and of the Top 100 listed organizations on BSE to the next question: Could you give grades from 1 to 10 for each item listed below, according to its importance for the success of the company where you work? (items: knowledge and skills of human capital, relations with customers, suppliers relations, company image, customers loyalty, alliances, partnerships, etc. organizational culture, professional skills of employees, work experience, employees loyalty, employees satisfaction, employees education, employees creativity, corporate reputation) and, also, the data from the 2009 financial statements (profit, total assets, current liabilities, outstanding payments, long-term debt, debt ratio, liquidity, solvency, capital, permanent capital, current assets, turnover, economic return, return on equity). The question is part of a questionnaire sent on 01.07.2010, by e-mail to 94 companies (26 knowledgebased organizations and 68 companies from Top 100). We received responses from 52 companies from Top 100 and 21 knowledge-based organizations listed on the BSE. We have chosen as a dependent variable the economic rate of return (ROA).

The standardization has been used because the analyzed variables had very different values; after that the variables are measured on the same scale (standard errors and their averages are between 0 and 1). Since values were standardized, free term is zero and does not appear in equation (Niculescu-Aron, 2007).

We kept in model only items that have significance level (Sig.) less than 0.05 (Ho, 2006), which shows that between independent variables (suppliers relations - Sig $=0.000$; company image $-\mathrm{Sig}=0.001$; employees satisfaction $-\mathrm{Sig}=$ 0.000 ; corporate reputation $-\mathrm{Sig}=0.033$; liquidity $-\mathrm{Sig}=$ 0.000 ; debt ratio - Sig $=0.000$; shareholder's equity $\mathrm{Sig}=$ $0.000)$ and the dependent variable (ROA) is a strong connection (Table 1).

\begin{tabular}{|c|c|c|c|c|c|}
\hline \multirow{2}{*}{ Model } & \multicolumn{2}{|c|}{$\begin{array}{c}\text { Unstandardized } \\
\text { Coefficients }\end{array}$} & $\begin{array}{c}\text { Standardized } \\
\text { Coefficients }\end{array}$ & \multirow{2}{*}{$\mathrm{t}$} & \multirow{2}{*}{ Sig. } \\
\cline { 2 - 5 } & $\mathrm{B}$ & $\begin{array}{c}\text { Std. } \\
\text { Error }\end{array}$ & Beta & & \\
\hline suppliers relations & -4.361 & 1.020 & -1.127 & -4.277 & .000 \\
\hline company image & 4.177 & 1.202 & 1.063 & 3.474 & .001 \\
\hline employees satisfaction & 3.862 & 1.054 & .906 & 3.663 & .000 \\
\hline corporate reputation & -2.585 & 1.197 & -.678 & -2.160 & .033 \\
\hline liquidity & -.136 & .017 & -.789 & -7.979 & .000 \\
\hline debt ratio & -.656 & .034 & -1.371 & - & 19.111 \\
\hline shareholders' equity & $2.287 \mathrm{E}-8$ & .000 & 1.563 & 9.353 & .000 \\
\hline
\end{tabular}

Tab. 1. Coefficients

First we tested if there were aberrant differences between values of the same variable of the analyzed population. From the figure no. 1 it can be seen that were seven cases $(5,7,17$, $35,43,44$ and 53) with extreme values which could distort the results of multiple regression. After we had eliminated them, the values followed a normal distribution (Figure no. 2).

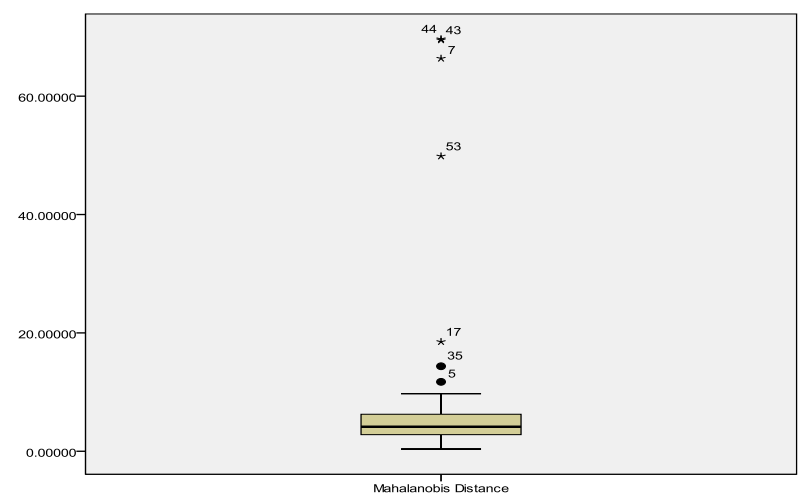

Fig. 1. Mehalanobis Distance 


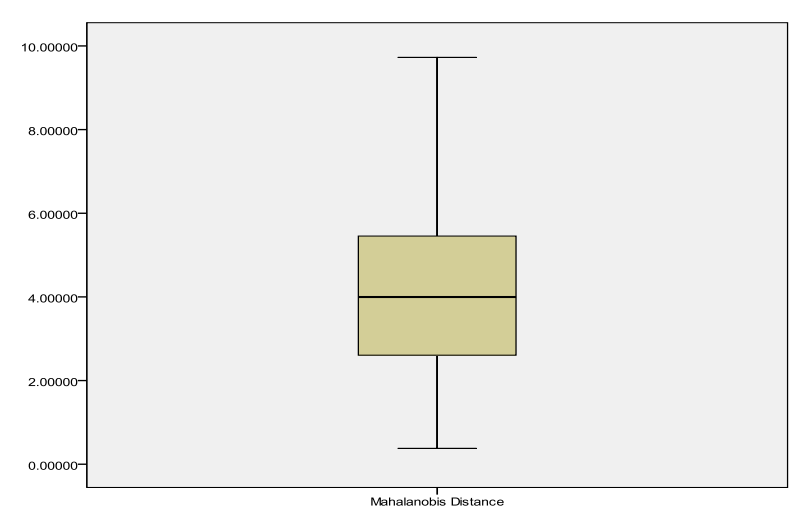

Fig. 2. Mehalanobis Distance

Next, we tested if were violated other assumptions, as normality, linearity and homeoscedascticity through evaluation of residuals mathematical diagrams (residuals scatter plots). The diagram (Figure no. 3 ) does not show abnormal vales (have not appeared the box Casewise Diagnostics, showing deviations from normal values).

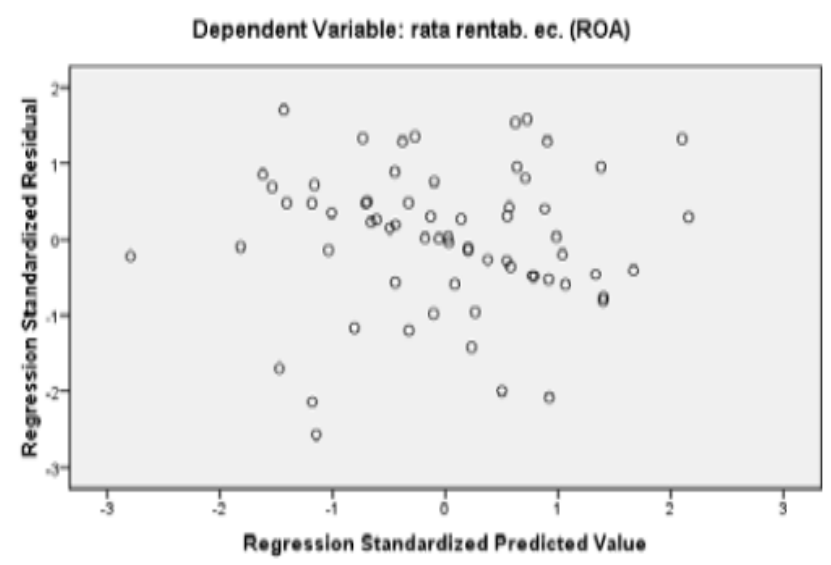

Fig. 3. Scatter plot

We also tested the multicollinearity. One of the diagnostic tools can be found in the Tolerance and Variance Inflation Factor (VIF) (Meyers et al., 2006). The tolerance of all predictors is bigger than 0.01 and VIF values are lower than 10, so multicollinearity is not a problem (Table no. 2).

\begin{tabular}{|c|c|c|c|c|c|c|}
\hline \multirow{2}{*}{ Model } & \multicolumn{2}{|c|}{$\begin{array}{c}\text { Unstandardized } \\
\text { Coefficients }\end{array}$} & \multirow{2}{*}{$\mathrm{t}$} & \multirow{2}{*}{ Sig. } & \multicolumn{2}{|c|}{$\begin{array}{c}\text { Collinearity } \\
\text { Statistics }\end{array}$} \\
\hline & B & $\begin{array}{l}\text { Std. } \\
\text { Error }\end{array}$ & & & Tolerance & VIF \\
\hline $\begin{array}{l}\text { suppliers } \\
\text { relations }\end{array}$ & -.153 & .018. & -8.725 & .000 & .749 & 1.336 \\
\hline $\begin{array}{l}\text { company } \\
\text { image }\end{array}$ & -.679 & .051 & 13.326 & .000 & .722 & 1.386 \\
\hline $\begin{array}{l}\text { employees } \\
\text { satisfaction }\end{array}$ & $\begin{array}{c}1.826 \mathrm{E}- \\
8\end{array}$ & .000 & 10.415 & .000 & .928 & 1.078 \\
\hline $\begin{array}{l}\text { corporate } \\
\text { reputation }\end{array}$ & -4.003 & 1.572 & -2.546 & .013 & .718 & 1.393 \\
\hline liquidity & 4.029 & 1.978 & 2.037 & .046 & .563 & 1.776 \\
\hline debt ratio & 4.119 & 1.841 & 2.237 & .029 & .251 & 3.991 \\
\hline $\begin{array}{c}\text { shareholders' } \\
\text { equity }\end{array}$ & -4.996 & 2.182 & -2.289 & .025 & .688 & 1.453 \\
\hline
\end{tabular}

Tab. 2. Coefficients

Table no. 3 provides a variety of measures assessing the success of the model in predicting the dependent variable. The adjusted $R^{2}$ is 0.639 , so about $63.9 \%$ of the criterion variable's variance is explained by regression model.

\begin{tabular}{|c|c|c|c|c|}
\hline Model & $\mathrm{R}$ & R Square $^{\mathrm{d}}$ & $\begin{array}{c}\text { Adjusted R } \\
\text { Square }\end{array}$ & $\begin{array}{c}\text { Std. Error of the } \\
\text { Estimate }\end{array}$ \\
\hline 1 & $.815^{\mathrm{a}}$ & .663 & .639 & 6.39679 \\
\hline
\end{tabular}

Tab. 3. Model Summary

Table no. 4 provides a summary of the analysis of variance regression. Because $F(8.49)=27.165, p<0.00$, we can say that there is a significant relationship between the independent variables and the dependent variable.

\begin{tabular}{|c|c|c|c|c|c|c|}
\hline \multicolumn{2}{|c|}{ Model } & $\begin{array}{c}\text { Sum of } \\
\text { Squares }\end{array}$ & df & $\begin{array}{c}\text { Mean } \\
\text { Square }\end{array}$ & F & Sig. \\
\hline \multirow{2}{*}{1} & Regression & 10003.964 & 7 & 1111.552 & 27.165 & 0,000 \\
\cline { 2 - 7 } & Residual & 5073.942 & 59 & 40.919 & & \\
\cline { 2 - 7 } & Total & $15077.906^{\mathrm{b}}$ & 66 & & & \\
\hline
\end{tabular}

Tab. 4. ANOVA

The coefficients (table no. 2) are significant predictors because sig < 0.05 (Pecican, 2007).

Multiple regression is defined by the equation (Meyers et al., 2006):

$$
\mathrm{Y}_{\text {pred }}=\beta_{1} \mathrm{x}_{\mathrm{z} 1}+\beta_{2} \mathrm{x}_{\mathrm{z2}}+\ldots \ldots \ldots \beta_{\mathrm{n}} \mathrm{x}_{\mathrm{zn}}
$$

Where:

$\mathrm{Y}_{\text {pred_dependent variable }}$

$\beta_{1}, \beta_{2} \ldots \ldots . \beta_{n}$-regression coefficients

$\mathrm{x}_{\mathrm{z} 1}, \mathrm{x}_{\mathrm{z} 2} \ldots \ldots \ldots \mathrm{x}_{\mathrm{zn}-}$ independent variables

In our case the regression line is:

$\mathrm{ROA}=(-1.127) *$ suppliers relations $+1.063 *$ company image $+0.906 *$ employees satisfaction $+(-0.678) *$ reputation of the organization $+(-0.789) *$ liquidity $+(-1.371) *$ debt ratio + $1.563 *$ shareholders' equity.

\section{CONCLUSION}

ROA can be explained by the indicators calculated and is influenced by elements from the traditional financial statements (liquidity, debt ratio, shareholders' equity), but also by intangible elements unrecorded in traditional financial statements (suppliers relations, company image, employee satisfaction, corporate reputation). Also, one can say that the model shows that $63.9 \%$ of observations are explained using the developed model. The unexplained observations can be justified by using a small number of observations (21 knowledge-based listed on BSE), due to the lack of companies that can be classified as knowledge-based organizations listed on BSE and also by managers' reluctance of providing information on questionnaires.

\section{REFERENCES}

Ho, R. (2006). Handbook of Univariate and Multivariate Data Analysis and Interpretation with SPSS, Taylor \& Francis Group, ISBN 978-1584886020, Florida

Luthy, H. (1998). Intellectual Capital and Its Measurement, http://www.3.bus.osaka-

cu.ac.jp/apira98/archives/htmls/25.htm, Accessed on: 200906-10

Meyers, L. S.; Gamst, G. \& Guarino, A. J. (2006). Applied Multivariate Research. Design and Interpretation, Sage Publication, ISBN 978-1412904124, London

Niculescu-Aron, G. (2007). Metode econometrice pentru afaceri, ASE Publishing, ISBN 978-973-594-996-9, Bucharest

Pecican, E. S. (2007) Econometrie pentru... economisti, Publishing Economica, ISBN 978-973-709-340-0, Bucharest

***(2011)http://www.bvb.ro/ListedCompanies/SocietatiMain.a spx, Accessed on:2010-07-30 